\title{
FAKTORISASI GRAF BARU YANG DIHASILKAN DARI PEMETAAN TITIK GRAF SIKEL PADA BILANGAN BULAT POSITIF
}

\author{
Nova Nevisa Auliatul Faizah' ${ }^{1}$ H. Wahyu H. Irawan ${ }^{2}$ \\ ${ }^{1}$ Mahasiswa Jurusan Matematika, Fakultas Sains dan Teknologi, UIN Maulana Malik Ibrahim Malang \\ ${ }^{2}$ Dosen Jurusan Matematika, Fakultas Sains dan Teknologi, UIN Maulana Malik Ibrahim Malang \\ E-mail: novanevisa@yahoo.com, henky_lily@yahoo.com
}

\begin{abstract}
ABSTRAK
Faktor merupakan subgraf merentang dari suatu graf. Subgraf merentang terdiri dari himpunan pasangan titik yang tidak saling terhubung dan selalu berbentuk graf beraturan satu, ini dapat disebut sebagai graf yang memiliki 1-faktor. Ketika himpunan titik dari graf sikel $C_{n}$ dipetakan pada bilangan bulat positif yang dibatasi oleh derajatnya maka akan menghasilkan graf baru $C_{n}{ }^{*}$ yang memiliki 1-faktor dengan ciri-ciri fungsi tertentu. Tujuan penelitian ini adalah untuk mengetahui ciri-ciri fungsi yang menghasilkan graf baru $C_{n}^{*}$ yang dihasilkan dari graf $C_{n}$ akan memiliki 1-faktor.

Adapun Langkah-langkah untuk memperoleh hasil dari penelitian ini adalah: (1) menggambar graf sikel $C_{n}$, (2) menentukan kemungkinan-kemungkinan dari fungsi $f\left(C_{n}\right) \rightarrow\{1,2\}$, (3) menentukan $D(x)$, (4) menentukan $s(x)$ dan $S(x)$, (5) Menentukan graf baru $C_{n}^{*}=\left(V^{*}, E^{*}\right)$, (6) Faktorisasi graf baru $C_{n}^{*}$ dengan menunjukkan himpunan pasangannya.

Hasil dari penelitian ini adalah ciri-ciri fungsi yang menghasilkan graf baru $C_{n}^{*}$ yang memiliki 1faktor dengan membedakan untuk banyak titik ganjil dan banyak titik genap sebagaimana berikut:

1. Fungsi dengan banyak $n$ atau satu titik dipetakan ke 2 untuk $n$ ganjil

2. Fungsi dengan banyak $n$ titik dipetakan ke 2 atau 1 untuk $n$ genap
\end{abstract}

Bagi penelitian selanjutnya diharapkan dapat mengembangkan penelitian ini untuk graf lainnya.

Kata Kunci: Faktorisasi, 1-faktor, f-faktor, Graf Sikel $\left(C_{n}\right)$

ABSTRACT

Factor is a spanning subgraph of a graph. Spanning subgraph consist of a set of couples of vertices that disconnected each other and always organized as regular graph one, called as a graph that has 1factor. When a set of points of Cycle Graph $\left(C_{n}\right)$ mapped on a positive integerbordered by its degree, it will produce a new graph of $C_{n}{ }^{*}$ that has 1-factor with the particular function's characteristics. The aim of this study is to determine the function's characteristics that produc a new graph of $C_{n}{ }^{*}$ obtained from $C_{n}$ of having 1-factor.

Therefore, the steps to provide the result of the research are: (1) drawing the Cycle Graph $C_{n}$, (2) Determining the possibility function of $f\left(C_{n}\right) \rightarrow\{1,2\}$, (3) Determining $D(x)$, (4) Determining $s(x)$ dan $S(x)$, (5) Determining a new graph $C_{n}^{*}=\left(V^{*}, E^{*}\right),(6)$ Factorizing the new graph $C_{n}^{*}$ with showing a set matching.

The results of this research are the function's characteristics that producing a new graph of $C_{n}{ }^{*}$ of having 1-factor with differentiate for many odd points and even points as follow:

1. A function of $n$ or one vertex has mapped to 2 for $n$ odd

2. A function of $n$ vertices is mapped to 2 or 1 for $n$ even.

For the further research is expected to another graph.

Keyword: Factoritation, 1-factor, f-factor, Graph Cycle $\left(C_{n}\right)$

\section{PENDAHULUAN}

Teori graf merupakan salah satu cabang ilmu Matematika yang sebenarnya sudah ada sejak dua ratus tahun yang lalu. Graf digunakan untuk mempresentasikan objek-objek diskrit dan hubungan antara objek-objek tersebut. Representasi visual dari graf adalah dengan menyatakan objek sebagai noktah, bulatan, atau titik, sedangkan hubungan antara objek dinyatakan dengan garis (Munir, 2012). Secara sistematis, menurut (Chartrand \& Lesniak, 1986) 
graf didefinisikan sebagai himpunan titik $V(G)$ yang tak kosong dan himpunan sisi $E(G)$ yang mungkin kosong yang mana keduanya saling berhubungan.

Dalam perkembangannya, jurnal pertama yang ditulis tentang teori graf muncul pada tahun 1736 oleh matematikawan terkenal dari Swiss bernama Euler (Budayasa, 2007). Perkembangan teori ini tidak hanya secara teoritis, tetapi juga secara aplikatif. Dalam perkembangan teoritis, konsep-konsep yang ada dapat dibuktikan secara deduksi dan induksi. Sedangkan perkembangan secara aplikatif merupakan terapan dari hasil teoritis sebagai penyelesaian dari suatu masalah nyata.

Salah satu topik yang menarik adalah membahas tentang faktorisasi. Menurut (Chartrand \& Lesniak, 1986), faktor adalah subgraf merentang dari suatu graf dan faktorisasi adalah penjumlahan sisi-sisi yang disjoint dari faktor-faktor suatu graf. Selanjutnya r-reguler faktor dapat dinyatakan sebagai r-faktor. Karena faktorisasi dari suatu graf akan selalu menghasilkan faktor-faktor graf yang beraturan satu, maka graf tersebut dapat dinyatakan memiliki 1-faktor. Sedangkan pasangan sempurna adalah himpunan pasangan titik yang membentuk sisi pada suatu graf yang tidak saling terhubung langsung. Melihat definisi pasangan sempurna ini dapat mewakili definisi dari faktor maka dapat dinyatakan bahwa suatu graf yang mengandung pasangan sempurna akan memiliki 1-faktor.

Sejauh ini masalah yang sudah dikaji tentang faktorisasi adalah faktorisasi graf komplit oleh Vera Mandailina tahun 2009 dan faktorisasi graf beraturan- $r$ dengan order genap oleh Asna Bariroh tahun 2010, kedua masalah ini hanya membahas tentang faktorisasi pada graf yang hanya menghasilkan berapa banyak faktor pada suatu graf. Jika permasalahan faktorisasi ini dikaitkan dengan sebuah pemetaan dari himpunan titik suatu graf pada bilangan bulat positif yang dibatasi oleh derajatnya maka akan berakibat terbentuknya graf baru yang mana graf baru tersebut tidak selalu memiliki 1-faktor. Oleh karena itu peneliti tertarik untuk mengembangkannya lebih lanjut.

\section{METODE PENELITIAN}

Penelitian ini bertujuan untuk mengembangkan permasalahan tentang faktorisasi, sehingga metode penelitian ini merupakan metode kepustakaan, pendekatan yang digunakan ialah pendekatan kualitatif yang pada umumnya tidak terjun ke lapangan dalam pencarian dan pengumpulan sumber datanya. Sedangkan pola pembahasannya dari induktif ke deduktif, hal ini berarti pembahasannya dimulai dari hal-hal khusus menuju pada hal-hal umum (generalisasi). Secara garis besar langkah penelitian ini sebagai berikut:

1) Menggambar graf sikel $\left(C_{n}\right)$ dengan $n$ bilangan ganjil.

2) Menentukan fungsi $f: V\left(C_{n}\right) \rightarrow Z^{+}$dengan ketentuan $f(x) \leq d(x) \forall x \in V\left(C_{n}\right)$, karena derajat pada graf sikel $\left(C_{n}\right)$ selalu dua maka himpunan $Z^{+}=\{1,2\}$ sehingga fungsinya dapat ditulis $f: V\left(C_{n}\right) \rightarrow\{1,2\}$. Kemudian menuliskan semua kemungkinan pemetaan yang terjadi.

3) Menentukan $D(x)=\left\{x_{\alpha} \mid \alpha \in E\left(C_{n}\right), \alpha\right.$ adalah sisi yang terkait langsung dengan $x ; \forall x \in$ $\left.V\left(C_{n}\right)\right\}$.

4) Menentukan $s(x)=d(x)-f(x) \forall x \in V\left(C_{n}\right)$ yang didefinisikan sebagai bilangan yang dihasilkan dari selisih antara derajat titik di graf sikel $\left(C_{n}\right)$ dan bilangan bulat positif dari fungsi $f: V\left(C_{n}\right) \rightarrow Z^{+}$, kemudian menentukan $S(x)=\{x(i) \mid 1 \leq i \leq s(x)\} \quad$ yang berupa himpunan titik dari $s(x)$.

5) Menentukan graf baru $C_{n}{ }^{\star}=\left(V^{\star}, E^{\star}\right)$, yang masing-masing dari $V^{\star}$ dan $E^{\star}$ didefinisikan sebagai berikut:

$$
\begin{array}{lr}
\text { a. } V^{\star}=V^{\star}{ }_{1} \cup V^{\star}{ }_{2} ; V^{\star}{ }_{1}=\bigcup_{x \in V\left(C_{n}\right)} D(x) \\
& ; V^{\star}{ }_{2}=\bigcup_{x \in V\left(C_{n}\right)} S(x) \\
\text { b. } E^{\star}=E^{\star}{ }_{1} \cup E^{\star}{ }_{2} ; & E^{\star}{ }_{1}=\left\{x_{\alpha} y_{\alpha} \mid \alpha=x y \in\right. \\
E\left(C_{n}\right) \quad & E^{\star}{ }_{2}=\{u v \mid u \in \\
D(x) \text { dan } v \in &
\end{array}
$$

6) Faktorisasi graf baru $C_{n}{ }^{\star}$.

7) Membuat suatu konjektur berdasarkan ciriciri yang didapatkan.

8) Merumuskan konjektur sebagai suatu teorema, kemudian dibuktikan kebenarannya sehingga dapat dinyatakan benar secara umum.

9) Menuliskan laporan penelitian.

\section{TEORI DASAR}

\section{Definisi Graf Sike}

Sikel dengan 3 atau lebih titik adalah suatu graf sederhana yang titiknya tersusun mengikuti putaran seperti suatu jalan dengan dua titik yang terhubung langsung jika keduanya berturutan dan tidak terhubung langsung dengan lainnya. Sebuah sikel dengan satu titik disebut loop, dan sikel dengan dua titik yang dihubungkan oleh dua sisi disebut sisi rangkap (Bondy \& Murty, 2008).

Contoh 2.2: Graf sikel $C_{n}$ dengan $n=3,4,5,6$

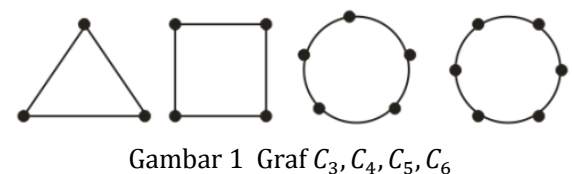

Gambar 1 Graf $C_{3}, C_{4}, C_{5}, C_{6}$ 


\section{Definisi Subgraf Merentang}

Subgraf $H$ dari graf $G$ yang memiliki himpunan titik yang sama pada $G$ atau jika subgraf $H$ dengan $V(H)=V(G)$, maka $H$ disebut spanning subgraf (Subgraf merentang) dari $G$ (Chartrand \& Lesniak, 1986).

Dari definisi sub graf merentang, peneliti memberikan contoh sebagai berikut:

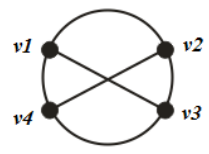

G

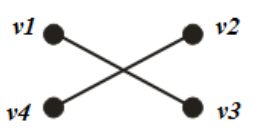

$G_{1}$
Gambar 2 Subgraf Merentang Graf $G_{1}$ dari Graf $G$

\section{Definisi Matching}

Matching (Pasangan) pada graf $G$ adalah himpunan pasangan titik yang membentuk sisi pada graf $G$ yang tidak saling terhubung langsung (Chartrand \& Lesniak, 1986).

\section{Definisi Perfect Matching}

$M$ disebut sebagai perfect matching (pasangan sempurna) pada graf $G$, jika $M$ merupakan suatu pasangan pada graf $G$, dan semua sisi di $M$ menutup semua titik di $G$ (Bondy \& Murty, 2008).

\section{Definisi Perfect Matching}

$M$ disebut sebagai perfect matching (pasangan sempurna) pada graf $G$, jika $M$ merupakan suatu pasangan pada graf $G$, dan semua sisi di $M$ menutup semua titik di $G$ (Bondy \& Murty, 2008).

Contoh diberikan graf $G$ dan graf $H$ sebagai berikut:

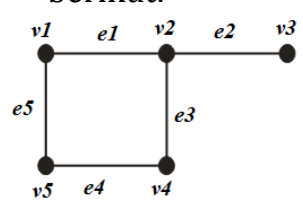

G

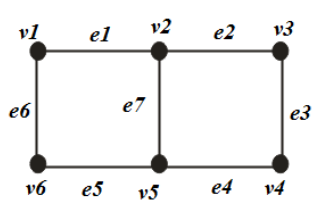

$H$
Gambar 3 Graf $G$ dan graf $H$

Dari Gambar 3 Graf $G$ dengan $M=\left\{e_{1}, e_{4}\right\}$ merupakan pasangan tidak sempurna dan graf $H$ dengan $M=\left\{e_{1}, e_{3}, e_{5}\right\}$ adalah pasangan sempurna.

\section{Definisi Faktor}

Faktor dari graf $G$ adalah suatu subgraf merentang dari graf $G$ (Chartrand \& Lesniak, 1986).

Jika $G_{1}, G_{2}, \ldots, G_{n}$ adalah faktor yang disjoint sisi pada graf $G$ sedemikian hingga $\cup_{i=1}^{n} E\left(G_{i}\right)=E(G)$ dimana $G=G_{1} \oplus G_{2} \oplus$ ... $\oplus G_{n}$ disebut sebagai penjumlahan sisi dari faktor-faktor $G_{1}, G_{2}, \ldots, G_{n}$.

\section{Definisi Faktorisasi}

Faktorisasi dari graf $G$ adalah penjumlahan sisi dari faktor-faktor graf (Chartrand \& Lesniak, 1986).

Suatu $r$-reguler faktor dari graf $G$ dapat dinyatakan sebagai r-faktor dari $G$. Oleh karena itu, suatu graf memiliki 1-faktor jika dan hanya jika mengandung suatu perfect matching.

contoh faktorisasi dari graf $G$ sebagai berikut:

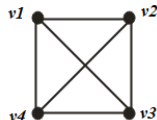

G

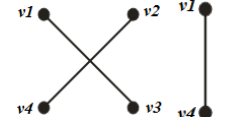

G1

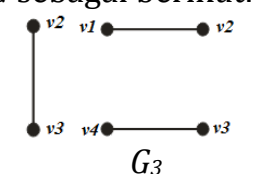

$G_{2}$
$G_{3}$
Gambar 2.9 Garf $G$ dan Faktor-faktornya

Berdasarkan buku Extremal Graph Theory peneliti menyimpulkan bahwa untuk membangun graf baru $G^{*}$ dari graf $G$ yang memiliki 1-faktor adalah dengan langkah-langkah sebagai berikut:

1) Menentukan fungsi $f: V(G) \rightarrow Z^{+}$dengan ketentuan $f(x) \leq d(x) \forall x \in V(G)$.

2) Menentukan $D(x)=\left\{x_{\alpha} \mid \alpha \in E(G), \alpha\right.$ adalah sisi yang terkait langsung dengan $x ; \forall x \in$ $V(G)\}$.

3) Menentukan $s(x)=d(x)-f(x) \forall x \in V(G)$ ), kemudian menentukan $S(x)=\{x(i) \mid 1 \leq i \leq$ $s(x)\}$

4) Menentukan graf baru $G^{\star}=\left(V^{\star}, E^{\star}\right)$ dengan $V^{\star}$ dan $E^{\star}$ didefinisikan sebagai berikut:

a. $V^{\star}=\left\{V^{\star}{ }_{1} U V^{\star}{ }_{2} \mid V^{\star}{ }_{1}=\bigcup_{x \in V(G)} D(x) \operatorname{dan} V^{\star}{ }_{2}=\right.$

$$
\text { b. } E^{\star}=\stackrel{\left.\bigcup_{x \in V(G)} S(x)\right\}}{\left\{E^{\star}{ }_{1} \cup E^{\star}{ }_{2} \mid E^{\star}{ }_{1}=\left\{x_{\alpha} y_{\alpha} \mid \alpha=x y \in E(G)\right\}\right.}
$$

dan $\left.E^{\star}{ }_{2}=\{u v \mid u \in D(x), v \in S(x), x \in V(G)\}\right\}$.

5. Faktorisasi graf baru $G^{\star}=\left(V^{\star}, E^{\star}\right)$ dengan menunjukkan adanya himpunan pasangan sempurna.

Dari graf baru $G^{*}$ yang dibangun tersebut maka terbentuklah lemma sebagai berikut:

\section{Lemma 1}

$G$ memiliki f-faktor jika dan hanya jika $G^{*}$ memiliki 1-faktor (Bollobas, 1978).

Bukti:

Misalkan $G$ memiliki f-faktor dengan himpunan sisi $F \subset E$. Maka $\psi(F)$ memuat sisi yang bebas dan dalam setiap himpunan $D(x)$ pasti titik $s(x)$ tidak tertutup oleh $\psi(F)$. Untuk setiap $x$ kita menambahkan $s(x)$ yang bebas dengan sisi $D(x)-S(x)$ yang menutup titik-titik yang lain dari $D(x)$. Dengan cara ini kita memperoleh $G^{*}$ memiliki 1-faktor.

Sebaliknya jika $G^{*}$ mempunyai 1-faktor dengan himpunan sisi $F^{*} \subset E^{*}$ kemudian $\psi^{-1}\left(F^{*} \cap E^{*}\right)$ adalah himpunan sisi dari f-faktor di $G$.

Contoh Diberikan graf komplit $K_{4}$ 


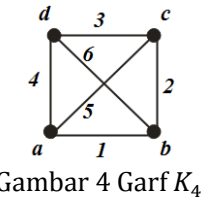

1. Menentukan fungsi $f: V\left(K_{4}\right) \rightarrow Z^{+}$dengan ketentuan $f(x) \leq d(x) \forall x \in V\left(K_{4}\right)$.

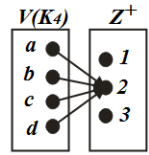

Gambar 5 Salah Satu Kemungkinan Fungsi $f: V\left(K_{4}\right) \rightarrow Z^{+}$

2. Menentukan $D(x)=\left\{x_{\alpha} \mid \alpha \in E\left(K_{4}\right), \alpha\right.$ adalah sisi yang terkait langsung dengan $x ; \forall x \in$ $\left.V\left(K_{4}\right)\right\}$.

$D(a)=\left\{a_{\alpha} \mid \alpha \in E\left(K_{4}\right)\right.$ dengan $\alpha=1, \quad \alpha=4$ dan $\alpha=5\}$ maka diperoleh $D(a)=\left\{a_{1}, a_{4}, a_{5}\right\}$ $D(b)=\left\{b_{\alpha} \mid \alpha \in E\left(K_{4}\right)\right.$ dengan $\alpha=1, \alpha=2$ dan $\alpha=6\}$ maka diperoleh $D(b)=\left\{b_{1}, b_{2}, b_{6}\right\}$ $D(c)=\left\{c_{\alpha} \mid \alpha \in E\left(K_{4}\right) \quad\right.$ dengan $\alpha=2, \alpha=3$ dan $\alpha=5\}$ maka diperoleh $D(c)=\left\{c_{2}, c_{3}, c_{5}\right\}$ $D(d)=\left\{d_{\alpha} \mid \alpha \in E\left(K_{4}\right)\right.$ dengan $\alpha=3, \alpha=4$ dan $\alpha=6\}$ maka diperoleh $D(d)=$ $\left\{d_{3}, d_{4}, d_{6}\right\}$

3. Menentukan $\left.s(x)=d(x)-f(x) \forall x \in V\left(K_{4}\right)\right)$, kemudian menentukan $S(x)=\{x(i) \mid 1 \leq i \leq$ $s(x)\}$.

$s(a)=d(a)-f(a)=3-2=1$

maka

diperoleh

$S(a)=\{a(i) \mid 1 \leq i \leq 1\}=\{a(1)\}$

$s(b)=d(b)-f(b)=3-2=1$

diperoleh

$S(b)=\{b(i) \mid 1 \leq i \leq 1\}=\{b(1)\}$

$s(c)=d(c)-f(c)=3-2=1$

diperoleh

$S(c)=\{c(i) \mid 1 \leq i \leq 1\}=\{c(1)\}$

$s(d)=d(d)-f(d)=3-2=1$ maka

diperoleh

$S(d)=\{d(i) \mid 1 \leq i \leq 1\}=\{d(1)\}$

4. Menentukan graf baru $G^{\star}=\left(V^{\star}, E^{\star}\right)$

a. $V^{\star}=V^{\star}{ }_{1} \cup V^{\star}{ }_{2}$

$V^{\star}{ }_{1}=\cup_{x \in V\left\{K_{4}\right)} D(x)=\{D(a) \cup D(b) \cup D(c) \cup$ $D(d)\}$

$=\left\{a_{1}, a_{4}, a_{5}, b_{1}, b_{2}, b_{6}, c_{2}, c_{3}, c_{5}, d_{3}, d_{4}, d_{6}\right\}$

$V^{\star}{ }_{2}=\cup_{x \in V\left(K_{4}\right)} S(x)=\{S(a) \cup S(b) \cup S(c)\}$ $=\{a(1), b(1), c(1), d(1)\}$

Sehingga untuk $V^{\star}=V^{\star}{ }_{1} \cup V^{\star}{ }_{2}$ diperoleh $V^{\star}=\left\{a_{1}, a_{4}, a_{5}, b_{1}, b_{2}, b_{6}, c_{2}, c_{3}, c_{5}, d_{3}, d_{4}, d_{6}\right.$, $a(1), b(1), c(1), d(1)\}$

b. $E^{\star}=E^{\star}{ }_{1} \cup E^{\star}{ }_{2}$

$E^{\star}{ }_{1}=\left\{x_{\alpha} y_{\alpha} \mid \alpha=x y \in E\left(K_{4}\right)\right\}$

$\alpha=1$ maka diperoleh $a_{1} b_{1}$

$\alpha=2$ maka diperoleh $b_{2} c_{2}$

$\alpha=3$ maka diperoleh $c_{3} d_{3}$

$\alpha=4$ maka diperoleh $d_{4} a_{4}$

$\alpha=5$ maka diperoleh $a_{5} c_{5}$

$\alpha=6$ maka diperoleh $b_{6} d_{6}$
Jadi, $E^{\star}{ }_{1}=\left\{a_{1} b_{1}, b_{2} c_{2}, c_{3} d_{3}, d_{4} a_{4}, a_{5} c_{5}, b_{6} d_{6}\right\}$ $E^{\star}{ }_{2}=\left\{u v \mid u \in D(x), v \in S(x), x \in V\left(K_{4}\right)\right\}$

$$
\begin{aligned}
= & \left\{a_{1} a(1), a_{4} a(1), a_{5} a(1), b_{1} b(1), b_{2} b(1),\right. \\
& b_{6} b(1), c_{2} c(1), c_{3} c(1), c_{5} c(1), d_{3} d(1), \\
& \left.d_{4} d(1), d_{6} d(1)\right\}
\end{aligned}
$$

Sehingga untuk $E^{\star}=E^{\star}{ }_{1} \cup E^{\star}{ }_{2}$ diperoleh

$$
\begin{aligned}
E^{\star}= & \left\{a_{1} b_{1}, b_{2} c_{2}, c_{3} d_{3}, d_{4} a_{4}, a_{5} c_{5}, b_{6} d_{6},\right. \\
& a_{1} a(1), a_{4} a(1), a_{5} a(1), b_{1} b(1), b_{2} b(1), \\
& b_{6} b(1), c_{2} c(1), c_{3} c(1), c_{5} c(1), d_{3} d(1), \\
& \left.d_{4} d(1), d_{6} d(1)\right\}
\end{aligned}
$$

Jadi, graf baru $K_{4}{ }^{\star}=\left(V^{\star}, E^{\star}\right)$ adalah

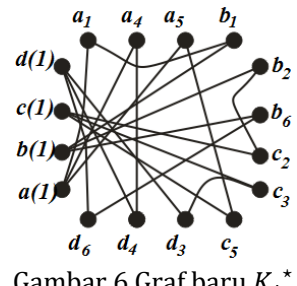

5. Faktorisasi graf baru $G^{\star}=\left(V^{\star}, E^{\star}\right)$ dengan menunjukkan adanya himpunan pasangan sempurna, yaitu $M=\left\{a_{1} b_{1}, a_{5} c_{5}, c_{3} d_{3}, b_{6} d_{6}\right.$, $\left.b_{2} b(1), c_{2} c(1), d_{4} d(1)\right\}$. Karena graf baru $G^{\star}=$ $\left(V^{\star}, E^{\star}\right)$ memuat pasangan sempurna maka graf baru $G^{\star}=\left(V^{\star}, E^{\star}\right)$ memiliki 1-faktor.

\section{PEMBAHASAN}

1. Faktorisasi Graf Baru $C_{3}$ * yang Dihasilkan dari Fungsi $f: V\left(C_{3}\right) \rightarrow\{1,2\}$

Pertama menggambar graf sikel $C_{3}$ dengan $a b=1, b c=2$, dan $c a=3$

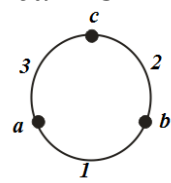

Gambar 7 Graf Sikel $C_{3}$

Selanjutnya menentukan semua kemungkinan fungsi $f: V\left(C_{3}\right) \rightarrow\{1,2\}$ adalah sebagai berikut:

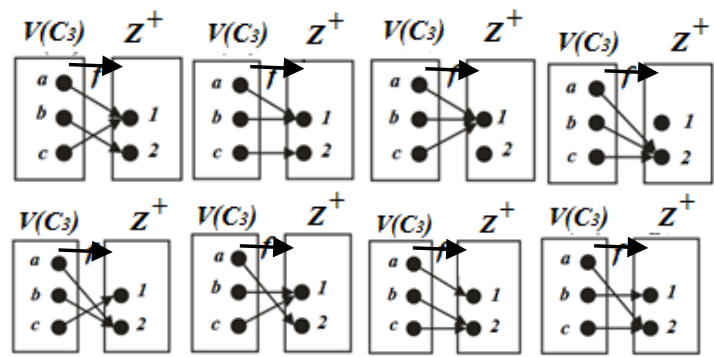

Gambar 8 Semua Kemungkinan Fungsi $f: V\left(C_{3}\right) \rightarrow\{1,2\}$

Kemudian untuk langkah selanjutnya akan dikerjakan pada salah satu kemungkinan dari Gambar 8 sebagai sampel kemungkinan yang dijadikan acuan untuk mengerjakan kemungkinan-kemungkinan fungsi yang lain. Salah satu kemungkinan tersebut adalah: 


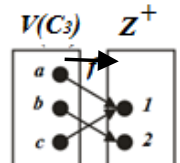

Gambar 9 Salah Satu Kemungkinan Fungsi $f: V\left(C_{3}\right) \rightarrow\{1,2\}$

Selanjutnya menentukan $D(x)=\left\{x_{\alpha} \mid \alpha=\right.$ $E\left(C_{3}\right), \alpha$ terkait langsung dengan $\left.x \in V\left(C_{3}\right)\right\}$

$D(a)=\left\{a_{\alpha} \mid \alpha \in E\left(C_{3}\right)\right.$ dengan $\alpha=1$ dan $\left.\alpha=3\right\}$ maka diperoleh $D(a)=\left\{a_{1}, a_{3}\right\}$

$D(b)=\left\{b_{\alpha} \mid \alpha \in E\left(C_{3}\right)\right.$ dengan $\alpha=1$ dan $\left.\alpha=2\right\}$ maka diperoleh $D(b)=\left\{b_{1}, b_{2}\right\}$

$D(c)=\left\{c_{\alpha} \mid \alpha \in E\left(C_{3}\right)\right.$ dengan $\alpha=2$ dan $\left.\alpha=3\right\}$ maka diperoleh $D(c)=\left\{c_{2}, c_{3}\right\}$

Selanjutnya menentukan $s(x)=d(x)-$ $f(x) \forall x \in V\left(C_{3}\right)$, kemudian menentukan $S(x)=$ $\{x(i) \mid 1 \leq i \leq s(x)\}$

$s(a)=d(a)-f(a)=2-1=1$ maka diperoleh

$S(a)=\{a(i) \mid 1 \leq i \leq 1\}=\{a(1)\}$

$s(b)=d(b)-f(b)=2-2=0$ maka diperoleh

$S(b)=\{b(i) \mid 1 \leq i \leq 0\}=\{\}$

$s(c)=d(c)-f(c)=2-1=1$ maka diperoleh

$S(c)=\{c(i) \mid 1 \leq i \leq 1\}=\{c(1)\}$

Selanjutnya menentukan graf baru $C_{3}{ }^{\star}=\left(V^{\star}, E^{\star}\right)$

a. $V^{\star}=V^{\star}{ }_{1} \cup V^{\star}{ }_{2}$

$V^{\star}{ }_{1}=\cup_{x \in V\left\{C_{3}\right)} D(x)=\{D(a) \cup D(b) \cup$

$D(c)\}=\left\{a_{1}, a_{3}, b_{1}, b_{2}, c_{2}, c_{3}\right\}$

$V^{\star}{ }_{2}=\cup_{x \in V\left(C_{3}\right)} S(x)=\{S(a) \cup S(b) \cup$

$S(c)\}=\{a(1), c(1)\}$

Sehingga untuk $V^{\star}=V^{\star}{ }_{1} \cup V^{\star}{ }_{2}$ diperoleh $V^{\star}=\left\{a_{1}, a_{3}, b_{1}, b_{2}, c_{2}, c_{3}, a(1), c(1)\right\}$

b. $E^{\star}=E^{\star}{ }_{1} \cup E^{\star}{ }_{2}$

$E^{\star}{ }_{1}=\left\{x_{\alpha} y_{\alpha} \mid \alpha=x y \in E\left(C_{3}\right)\right\}$

$\alpha=1$ maka diperoleh $a_{1} b_{1}$

$\alpha=2$ maka diperoleh $b_{2} c_{2}$

$\alpha=3$ maka diperoleh $c_{3} a_{3}$

Jadi, $E^{\star}{ }_{1}=\left\{a_{1} b_{1}, b_{2} c_{2}, c_{3} a_{3}\right\}$

$E^{\star}{ }_{2}=\left\{u v \mid u \in D(x), v \in S(x), x \in V\left(C_{3}\right)\right\}$

$=\left\{a_{1} a(1), a_{3} a(1), c_{2} c(1), c_{3} c(1)\right\}$

Sehingga untuk $E^{\star}=E^{\star}{ }_{1} \cup E^{\star}{ }_{2}$ diperoleh

$E^{\star}=\left\{a_{1} b_{1}, b_{2} c_{2}, c_{3} a_{3}, a_{1} a(1), a_{3} a(1), c_{2} c(1)\right.$, $\left.c_{3} c(1)\right\}$

Jadi, graf baru $C_{3}{ }^{\star}=\left(V^{\star}, E^{\star}\right)$ dari kemungkinan fungsi $f(a)=1, f(b)=2$, dan $f(c)=1$ adalah:

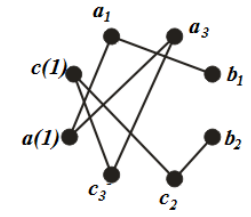

Gambar 10 Graf Baru $C_{3}$ * dari Sampel Kemungkinan Fungsi $f: V\left(C_{3}\right) \rightarrow\{1,2\}$

Selanjutnya faktorisasi graf baru $C_{3}{ }^{\star}$. Dari Gambar 10 didapatkan pasangan $M=$ $\left\{b_{2} c_{2}, c(1) c_{3}, a_{3} a(1), a_{1} b_{1}\right\}$ sebagai himpunan pasangan titik yang membentuk sisi yang tidak saling terhubung langsung. Karena titik-titik pada Gambar 10 bisa berpasang-pasangan dan merupakan pasangan sempurna, maka berakibat graf baru $C_{3}{ }^{\star}$ dari fungsi $f(a)=1, f(b)=2$, dan $f(c)=1$ memiliki 1 -faktor.

Selanjutnya untuk pembahasan kemungkinankemungkinan dari fungsi $f: V\left(C_{3}\right) \rightarrow\{1,2\}$ yang lain dapat dapat dilakukan dengan cara yang sama dan disimpulkan bahwa kemungkinankemungkinan fungsi yang menghasilkan graf baru $C_{3}{ }^{\star}$ yang memiliki 1 -faktor adalah sebagai berikut:

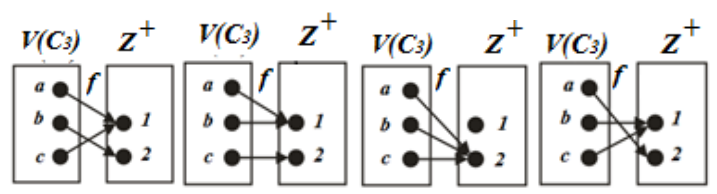

Gambar 11 Kemungkinan Fungsi $f: V\left(C_{3}\right) \rightarrow\{1,2\}$ yang Memiliki 1-Faktor

Maka dapat dibuat dugaan mengenai ciri-ciri fungsi yang mengakibatkan graf baru $C_{3}{ }^{*}$ yang dihasilkan dari fungsi $f: V\left(C_{3}\right) \rightarrow\{1,2\}$ akan memiliki 1-faktor dengan melihat banyaknya titik yang dipetakan yaitu fungsi dengan banyak $n$ titik atau hanya satu titik dipetakan ke 2 .

Untuk graf $\boldsymbol{C}_{\boldsymbol{n}}$ selanjutnya akan dilakukan dengan cara yang sama dan hanya akan ditunjukkan fungsi yang memiliki 1-faktor.

2. Faktorisasi Graf Baru $C_{4}{ }^{\star}$ yang Dihasilkan dari Fungsi $\boldsymbol{f}: \boldsymbol{V}\left(\boldsymbol{C}_{\mathbf{4}}\right) \rightarrow\{1,2\}$

Gambar graf sikel $\left(C_{4}\right)$ dengan $a b=$ $1, b c=2, c d=3, d e=4$

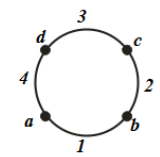

Gambar 12 Graf Sikel $C_{4}$

Kemungkinan-kemungkinan fungsi yang menghasilkan graf baru $C_{4}{ }^{\star}$ yang memiliki 1faktor adalah sebagai berikut:

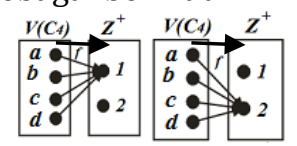

Gambar 13 Kemungkinan Fungsi $f: V\left(C_{4}\right) \rightarrow\{1,2\}$ yang Memiliki 1-faktor

\section{Faktorisasi Graf Baru $C_{5}$ * yang Dihasilkan dari Fungsi $f: V\left(C_{5}\right) \rightarrow\{1,2\}$}

Gambar graf sikel $C_{5}$ dengan $a b=1, b c=$ $2, c d=3, d e=4, e a=5$

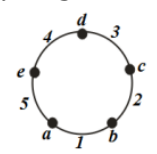

Gambar 14 Graf Sikel $C_{5}$

Kemungkinan-kemungkinan fungsi yang menghasilkan graf baru $C_{5}$ * yang memiliki 1faktor adalah sebagai berikut: 


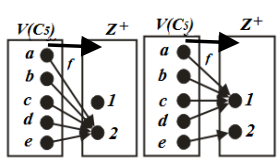

Gambar 15 Kemungkinan Fungsi $f: V\left(C_{5}\right) \rightarrow\{1,2\}$ yang Memiliki 1-faktor

4. Faktorisasi Graf Baru $C_{6}{ }^{\star}$ yang Dihasilkan dari Fungsi $f: V\left(C_{6}\right) \rightarrow\{1,2\}$

Gambar graf sikel $\left(C_{6}\right)$ dengan $a b=$ $1, b c=2, c d=3, d e=4, e f=5, f a=6$

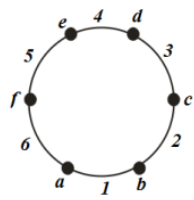

Gambar 3.10 Graf Sikel $C_{6}$

Kemungkinan-kemungkinan fungsi yang menghasilkan graf baru $C_{6}{ }^{\star}$ yang memiliki 1 faktor adalah sebagai berikut:

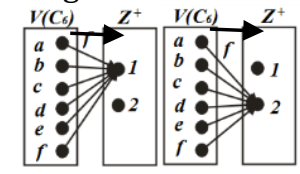

Gambar 15 Kemungkinan Fungsi $f: V\left(C_{6}\right) \rightarrow\{1,2\}$ yang Memiliki 1-faktor

5. Faktorisasi Graf Baru $C_{7}{ }^{\star}$ yang Dihasilkan dari Fungsi $f: V\left(C_{7}\right) \rightarrow\{1,2\}$

Gambar graf sikel $\left(C_{7}\right)$ dengan $a b=$ $1, b c=2, c d=3, d e=4, e f=5, f g=6, g a=7$

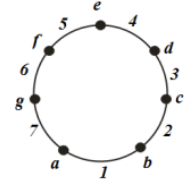

Gambar 16 Graf Sikel $C_{7}$

Kemungkinan-kemungkinan fungsi yang menghasilkan graf baru $C_{7}$ * yang memiliki 1 faktor adalah sebagai berikut:

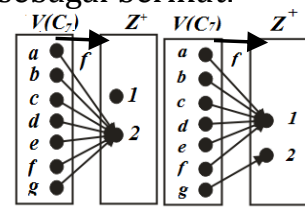

Gambar 17 Kemungkinan Fungsi $f: V\left(C_{7}\right) \rightarrow\{1,2\}$ yang Memiliki 1-faktor

\section{Faktorisasi Graf Baru $C_{8}{ }^{\star}$ yang Dihasilkan} dari Fungsi $f: V\left(C_{8}\right) \rightarrow\{1,2\}$

Pertama MengGambar graf sikel $\left(C_{8}\right)$ dengan $a b=1, b c=2, c d=3$, de $=4$, ef $=5$, $f g=6, g h=7, h a=8$

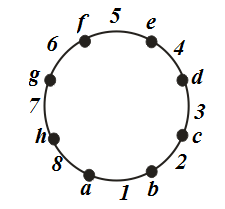

Gambar 18 Graf Sikel $C_{8}$

Kemungkinan-kemungkinan fungsi yang menghasilkan graf baru $C_{8}{ }^{\star}$ yang memiliki 1 faktor adalah sebagai berikut:

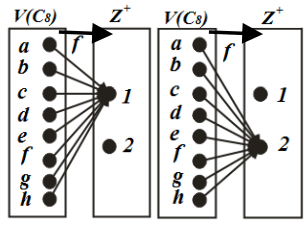

Gambar 19 Kemungkinan Fungsi $f: V\left(C_{8}\right) \rightarrow\{1,2\}$ yang Memiliki 1-faktor

7. Dugaan Ciri-ciri Fungsi $f: V\left(C_{n}\right) \rightarrow\{1,2\}$ yang Mengakibatkan Graf Baru $C_{n}$ * Memiliki 1-Faktor

Ciri-ciri fungsi yang mengakibatkan graf baru $C_{n}{ }^{\star}$ yang dihasilkan dari fungsi $f: V\left(C_{n}\right) \rightarrow$ $\{1,2\}$ akan memiliki 1 -faktor adalah:

Untuk $n$ ganjil

a. Fungsi dengan sebanyak $n$ titik dipetakan ke 2

b. Fungsi dengan sebanyak hanya satu titik dipetakan ke 2 .

Untuk $n$ genap

a. Fungsi dengan sebanyak $n$ titik dipetakan ke 2

b. Fungsi dengan sebanyak $n$ titik dipetakan ke 1 .

\section{Teorema 1:}

Fungsi yang mengakibatkan graf baru $C_{n}{ }^{\star}$ yang dihasilkan dari kemungkinankemungkinan fungsi $f: V\left(C_{n}\right) \rightarrow\{1,2\}$ dapat memiliki 1-faktor untuk $n$ ganjil $(n \geq 3)$ adalah fungsi dengan sebanyak $n$ titik atau hanya satu titik dipetakan ke 2 .

\section{Bukti:}

Misal $C_{n}$ adalah graf sikel dengan $n$ ganjil $(n \geq 3)$ dengan $V\left(C_{n}\right)=\left\{v_{1}, v_{2}, v_{3}, \ldots, v_{n}\right\}$ dan $E\left(C_{n}\right)=\left\{e_{1}, e_{2}, e_{3}, \ldots, e_{n}\right\}$ dengan $e_{i}=v_{i} v_{i+1}$ untuk $i=1,2, \ldots, n-1$ dan $e_{n}=v_{n} v_{1}$. Misalkan $C_{n}{ }^{*}$ adalah graf baru yang dihasilkan dari kemungkinan $\quad f: V\left(C_{n}\right) \rightarrow\{1,2\}$. Akan ditunjukkan bahwa $C_{n}{ }^{*}$ memiliki 1-faktor jika fungsinya memetakan sebanyak $n$ titik atau hanya satu titik dipetakan ke 2. Misal gambar graf $C_{n}$ adalah:

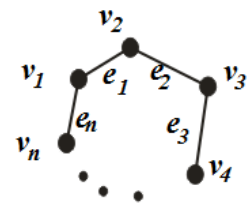

Gambar 20 Graf Sikel $C_{n}$ untuk $n$ Ganjil

Selanjutnya menentukan fungsi berdasarkan ciri-ciri yang telah ditentukan, yaitu: a. Fungsi dengan sebanyak $n$ titik dipetakan ke 2 Misalkan $f$ fungsi dari $V\left(C_{n}\right)$ ke $\{1,2\}$ dengan $f\left(v_{i}\right)=2$ untuk $i=1,2, \ldots, n$. Maka diperoleh:

$$
\begin{aligned}
D(x)= & \left\{v_{1_{e_{n}}}, v_{1_{e_{1}}}, v_{2_{e_{1}}}, v_{2_{e_{2}}}, v_{3_{e_{2}}}, v_{3_{e_{3}}}, .,\right. \\
& \left.v_{n_{e_{n-1}}}, v_{n_{e_{n}}}\right\} \\
S(x)=\{\} & \left\{v^{\star}=\left\{v_{1_{e_{n}}}, v_{1_{e_{1}}}, v_{2_{e_{1}}}, v_{2_{e_{2}}}, v_{3_{e_{2}}}, v_{3_{e_{3}}} \ldots,\right.\right. \\
& v_{\left.n_{e_{n-1}}, v_{n_{e_{n}}}\right\}} \\
E^{\star}= & \left\{v_{1_{e_{1}}} v_{2_{e_{1}}}, v_{2_{e_{2}}} v_{3_{e_{2}}}, \ldots, v_{n_{e_{n}}} v_{1_{e_{n}}}\right\}
\end{aligned}
$$


Jadi graf baru $C_{n}{ }^{*}=\left(V^{*}, E^{*}\right)$ dengan fungsi $f\left(v_{i}\right)=2$ untuk $i=1,2, \ldots, n$ adalah:

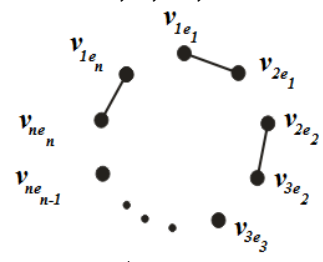

Gambar 21 Graf Baru $C_{n}{ }^{*}$ untuk $n$ Ganjil dari Fungsi $f\left(v_{i}\right)=2$ untuk $i=1,2, \ldots, n$

Selanjutnya dari Gambar 21 dilakukan faktorisasi dengan menunjukkan adanya pasangan yaitu dengan melihat pengembangan titik yang terjadi dari setiap titik di graf sikel $C_{n}$ berdasarkan masingmasing pemetaannya sebagaimana berikut:

Untuk $v_{1}$ dipetakan ke 2, maka diperoleh $D\left(v_{1}\right)=\left\{v_{1_{e_{n}}}, v_{1 e_{1}}\right\}$ dan $S\left(v_{1}\right)=\{\}$. Jadi titik $v_{1}$ berkembang menjadi $\left\{v_{1_{e_{n}}}, v_{1 e_{1}}\right\}$

Untuk $v_{2}$ dipetakan ke 2 , maka diperoleh $D\left(v_{2}\right)=\left\{v_{2_{e_{1}}}, v_{2_{e_{2}}}\right\}$ dan $S\left(v_{2}\right)=\{\}$. Jadi titik $v_{2}$ berkembang menjadi $\left\{v_{2_{e_{1}}}, v_{2_{e_{2}}}\right\}$

Untuk $v_{n}$ dipetakan ke 2, maka diperoleh $D\left(v_{n}\right)=\left\{v_{n_{e_{n-1}}}, v_{n_{e_{n}}}\right\}$ dan $S\left(v_{n}\right)=\{\}$. Jadi titik $v_{n}$ berkembang menjadi $\left\{v_{n_{e_{n-1}}}, v_{n_{e_{n}}}\right\}$.

Dari pengembangan titik ini dapat dilihat bahwa untuk setiap titik yang dipetakan ke 2 selalu berkembang menjadi 2 titik, karena sebanyak $n$ titik yang dipetakan ke 2 maka banyak pengembangannya adalah $2 n$ titik, dan karena $n=2 k+1$ maka $2 n=$ $2(2 k+1)$ bernilai genap. Kemudian dari simulasi Gambar 3.17 terlihat bahwa sisi-sisi yang terbentuk pada graf baru $C_{n}{ }^{*}$ berupa sisisisi yang berselang-seling dengan $M=$ $\left\{v_{1_{e_{1}}} v_{2_{e_{1}}}, v_{2_{e_{2}}} v_{3_{e_{2}}}, \ldots, v_{n_{e_{n}}} v_{1_{e_{n}}}\right\}$, maka dapat dipastikan graf baru $C_{n}{ }^{*}$ dengan fungsi sebanyak $n$ titik dipetakakan ke 2 akan selalu memiliki 1-faktor.

b. Fungsi dengan sebanyak hanya satu titik dipetakan ke 2

Misalkan $f$ fungsi dari $V\left(C_{n}\right)$ ke $\{1,2\}$ dengan $f\left(v_{i}\right)=1$ dan $f\left(v_{1}\right)=2$ untuk $i=2,3, \ldots, n$. Maka diperoleh:

$$
\begin{aligned}
& D(x)=\left\{v_{1_{e_{n}}}, v_{1_{e_{1}}}, v_{2_{e_{1}}}, v_{2_{e_{2}}}, v_{3_{e_{2}}}, v_{3_{e_{3}}} \ldots,\right. \\
& \left.v_{n_{e_{n-1}}}, v_{n_{e_{n}}}\right\} \\
& S(x)=\left\{v_{2}(1), v_{3}(1), \ldots, v_{n}(1)\right\} \\
& V^{\star}=\left\{v_{1_{e_{n}}}, v_{1_{e_{1}}}, v_{2_{e_{1}}}, v_{2_{e_{2}}}, v_{3_{e_{2}}}, v_{3_{e_{3}}} \ldots, v_{n_{e_{n-1}}},\right. \\
& \left.\quad v_{n_{e_{n}}}, v_{2}(1), v_{3}(1), \ldots, v_{n}(1)\right\} \\
& E^{\star} \\
& =\left\{v_{1_{e_{1}}} v_{2_{e_{1}}}, v_{2_{e_{2}}} v_{3_{e_{2}}}, \ldots, v_{n_{e_{n}}} v_{1_{e_{n}}}, v_{2_{e_{1}}} v_{2}(1),\right. \\
& \quad v_{2_{e_{2}}} v_{2}(1), v_{3_{e_{2}}} v_{3}(1), v_{e_{3}} v_{3}(1), \ldots, \\
& \left.v_{n_{e_{n-1}}} v_{n}(1), v_{n_{e_{n}}} v_{n}(1)\right\}
\end{aligned}
$$

Jadi graf baru $C_{n}{ }^{*}=\left(V^{*}, E^{*}\right)$ dengan fungsi $f\left(v_{i}\right)=1$ dan $f\left(v_{1}\right)=2$ untuk $i=2,3, \ldots, n$ adalah:

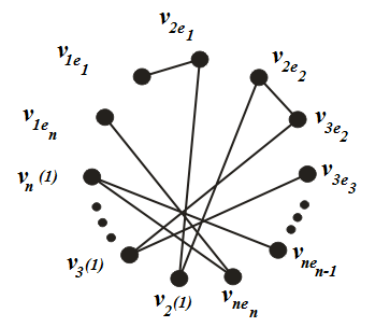

Gambar 22 Graf Baru $C_{n}{ }^{*}$ untuk $n$ Ganjil dari Fungsi $f\left(v_{i}\right)=1$ dan $f\left(v_{1}\right)=2$ untuk $i=2,3, \ldots, n$

Selanjutnya dari Gambar 22 dilakukan faktorisasi dengan menunjukkan adanya pasangan yaitu dengan melihat pengembangan titik yang terjadi dari setiap titik di graf sikel $C_{n}$ berdasarkan masingmasing pemetaannya sebagaimana berikut:

Untuk $v_{1}$ dipetakan ke 2, maka diperoleh $D\left(v_{1}\right)=\left\{v_{1_{e_{1}}}, v_{1_{e_{n}}}\right\}$ dan $S\left(v_{1}\right)=\{\}$. Jadi titik $v_{1}$ berkembang menjadi $\left\{v_{1_{e_{1}}}, v_{1_{e_{n}}}\right\}$

Untuk $v_{2}$ dipetakan ke 1 , maka diperoleh $D\left(v_{2}\right)=\left\{v_{2_{e_{1}}}, v_{2_{e_{2}}}\right\}$ dan $S\left(v_{2}\right)=\left\{v_{2}(1)\right\}$. Jadi titik $v_{2}$ berkembang menjadi $\left\{v_{2_{e_{1}}}, v_{2_{e_{2}}}, v_{2}(1)\right\}$

$$
\text { ! }
$$

Untuk $v_{n}$ dipetakan ke 1, maka diperoleh $D\left(v_{n}\right)=\left\{v_{n_{e_{n-1}}}, v_{n_{e_{n}}}\right\}$ dan $S\left(v_{n}\right)=\left\{v_{n}(1)\right\}$. Jadi titik $v_{n}$ berkembang menjadi $\left\{v_{n_{e_{n-1}}}, v_{n_{e_{n}}}, v_{n}(1)\right\}$.

Dari pengembangan titik ini dapat dilihat bahwa untuk setiap titik yang dipetakan ke 2 selalu berkembang menjadi 2 titik, karena sebanyak satu titik yang dipetakan ke 2 maka banyak pengembangannya adalah 2 titik, sedangkan untuk setiap titik yang dipetakan ke 1 selalu berkembang menjadi 3 titik, karena sebanyak $n-1$ titik yang dipetakan ke 1 maka banyak pengembangannya adalah $3(n-1)$. Jadi, secara keseluruhan perkembangan titiknya adalah sebesar $2+$ $3(n-1)$ titik. Karena $n=2 k+1$ maka $2+$ $3(n-1)=6 k+2$ bernilai genap. Kemudian dari simulasi Gambar 3.18 terlihat bahwa sisisisi yang terbentuk pada graf baru $C_{n}{ }^{*}$ akan selalu berbentuk lintasan, sehingga dapat ditunjukkan himpunan pasangannya adalah $M=\left\{v_{1_{e_{1}}} v_{2_{e_{1}}}, v_{2_{e_{2}}} v_{2}(1), v_{e_{e_{2}}} v_{3}(1) \ldots\right.$ ， $v_{n_{e_{n-1}}} v_{n}(1), v_{n_{e_{n}}} v_{1_{e_{n}}}$, maka dapat dipastikan graf baru $C_{n}{ }^{*}$ dengan fungsi sebanyak hanya satu titik dipetakakan ke 2 akan selalu memiliki 1-faktor.

\section{Teorema 2:}

Fungsi yang mengakibatkan graf baru $C_{n}{ }^{*}$ yang dihasilkan dari kemungkinan- 
kemungkinan fungsi $f: V\left(C_{n}\right) \rightarrow\{1,2\}$ dapat memiliki 1 -faktor untuk $n$ genap $(n \geq 4)$ adalah fungsi dengan sebanyak $n$ titik dipetakan ke 2 atau ke 1 .

\section{Bukti}

Misal $C_{n}$ adalah graf sikel dengan $n$ genap $(n \geq 4)$ dengan $V\left(C_{n}\right)=\left\{v_{1}, v_{2}, v_{3}, \ldots, v_{n}\right\}$ dan $E\left(C_{n}\right)=\left\{e_{1}, e_{2}, e_{3}, \ldots, e_{n}\right\}$ dengan $e_{i}=v_{i} v_{i+1}$ untuk $i=1,2, \ldots, n-1$ dan $e_{n}=v_{n} v_{1}$. Misalkan $C_{n}{ }^{*}$ adalah graf baru yang dihasilkan dari kemungkinan $\quad f: V\left(C_{n}\right) \rightarrow\{1,2\} . \quad$ Akan ditunjukkan bahwa $C_{n}{ }^{*}$ memiliki 1 -faktor jika fungsinya memetakan sebanyak $n$ titik dipetakan ke 2 atau ke 1. Misal gambar graf $C_{n}$ adalah:

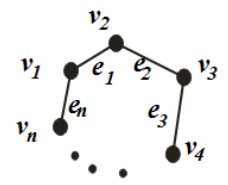

Gambar 23 Graf Sikel $C_{n}$ untuk $n$ Genap

Selanjutnya menentukan fungsi berdasarkan ciri-ciri yang telah ditentukan, yaitu: a. Fungsi dengan sebanyak $n$ titik dipetakan

ke 2

Misalkan $f$ fungsi dari $V\left(C_{n}\right)$ ke $\{1,2\}$ dengan $f\left(v_{i}\right)=2$ untuk $i=1,2, \ldots, n$. Maka diperoleh:

$$
\begin{aligned}
D(x)= & \left\{v_{1_{e_{n}}}, v_{1_{e_{1}}}, v_{2_{e_{1}}}, v_{2_{e_{2}}}, v_{3_{e_{2}}}, v_{3_{e_{3}}} \ldots,\right. \\
& \left.v_{n_{e_{n-1}}}, v_{n_{e_{n}}}\right\} \\
S(x)=\{\} & \\
V^{\star}= & \left\{v_{1_{e_{n}}}, v_{1_{e_{1}}}, v_{2_{e_{1}}}, v_{2_{e_{2}}}, v_{3_{e_{2}}}, v_{3_{e_{3}}} \ldots, v_{n_{e_{n-1}},},\right. \\
& \left.v_{n_{e_{n}}}\right\}
\end{aligned}
$$$$
E^{\star}=\left\{v_{1_{e_{1}}} v_{2_{e_{1}}}, v_{2_{e_{2}}} v_{3_{e_{2}}}, \ldots, v_{n_{e_{n}}} v_{1_{e_{n}}}\right\}
$$

Jadi graf baru $C_{n}{ }^{*}=\left(V^{*}, E^{*}\right)$ dengan fungsi $f\left(v_{i}\right)=2$ untuk $i=1,2, \ldots, n$ adalah:

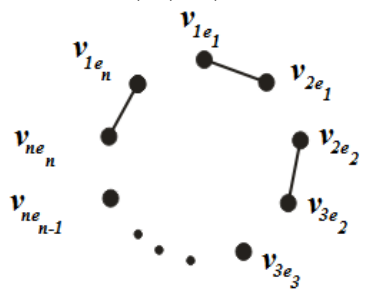

Gambar 24 Graf Baru $C_{n}{ }^{*}$ untuk $n$ Genap dari Fungsi

$$
f\left(v_{i}\right)=2 \text { untuk } i=1,2, \ldots, n
$$

Selanjutnya dari Gambar 24 dilakukan faktorisasi dengan menunjukkan adanya pasangan yaitu dengan melihat pengembangan titik yang terjadi dari setiap titik di graf sikel $C_{n}$ berdasarkan masingmasing pemetaannya sebagaimana berikut:

Untuk $v_{1}$ dipetakan ke 2, maka diperoleh $D\left(v_{1}\right)=\left\{v_{1 e_{n}}, v_{1 e}\right\}$ dan $S\left(v_{1}\right)=\{\}$. Jadi titik $v_{1}$ berkembang menjadi $\left\{v_{1 e_{n}}, v_{1 e_{1}}\right\}$

Untuk $v_{2}$ dipetakan ke 2, maka diperoleh $D\left(v_{2}\right)=\left\{v_{e_{e_{1}}}, v_{2_{e_{2}}}\right\}$ dan $S\left(v_{2}\right)=\{\}$. Jadi titik $v_{2}$ berkembang menjadi $\left\{v_{2_{e_{1}}}, v_{2_{e_{2}}}\right\}$
Untuk $v_{n}$ dipetakan ke 2, maka diperoleh $D\left(v_{n}\right)=\left\{v_{n_{e_{n-1}},}, v_{n_{e_{n}}}\right\}$ dan $S\left(v_{n}\right)=\{\}$. Jadi titik $v_{n}$ berkembang menjadi $\left\{v_{n_{e_{n-1}}}, v_{n_{e_{n}}}\right\}$.

Dari pengembangan titik ini dapat dilihat bahwa untuk setiap titik yang dipetakan ke 2 selalu berkembang menjadi 2 titik, karena sebanyak $n$ titik yang dipetakan ke 2 maka banyak pengembangannya adalah $2 n$ titik, dan karena $n=2 k+2$ maka $2 n=$ $2(2 k+2)$ bernilai genap. Kemudian dari simulasi Gambar 3.20 terlihat bahwa sisi-sisi yang terbentuk pada graf baru $C_{n}{ }^{*}$ berupa sisisisi yang berselang-seling dengan $M=$ $\left\{v_{1_{e_{1}}} v_{2_{e_{1}}}, v_{2_{e_{2}}} v_{3_{e_{2}}}, \ldots, v_{n+1} v_{e_{n+1}} v_{n+2} e_{e_{n+1}}\right.$, $v_{n+2} e_{n+2} v_{1_{e_{n+2}}}$, maka dapat dipastikan graf baru $C_{n}{ }^{*}$ dengan fungsi sebanyak $n$ titik dipetakakan ke 2 akan selalu memiliki 1faktor.

b. Fungsi dengan banyak $n$ titik dipetakan ke 1

Misalkan $f$ fungsi dari $V\left(C_{n}\right)$ ke $\{1,2\}$ dengan $f\left(v_{i}\right)=1$ untuk $i=1,2, \ldots, n$. Maka diperoleh: $D(x)=\left\{v_{1_{e_{n}}}, v_{1_{e_{1}}}, v_{2_{e_{1}}}, v_{2_{e_{2}}}, v_{3_{e_{2}}}, v_{3_{e_{3}}} \ldots\right.$, $\left.v_{n_{e_{n-1}}}, v_{n_{e_{n}}}\right\}$

$S(x)=\left\{v_{1}(1), v_{2}(1), v_{3}(1), \ldots, v_{n}(1)\right\}$

$$
\begin{aligned}
& V^{\star}=\left\{v_{1_{e_{n}}}, v_{1_{e_{1}}}, v_{2_{e_{1}}}, v_{2_{e_{2}}}, v_{3_{e_{2}}}, v_{3_{e_{3}}}, \ldots, v_{n_{e_{n-1}}},\right. \\
& \left.v_{n_{e_{n}}}, v_{1}(1), v_{2}(1), v_{3}(1), \ldots, v_{n}(1)\right\} \\
& E^{\star} \\
& \begin{array}{c}
=\left\{v_{1_{e_{1}}} v_{2_{e_{1}}}, v_{2_{e_{2}}} v_{3_{e_{2}}}, \ldots, v_{n_{e_{n}}} v_{1 e_{e_{n}}}, v_{1_{e_{n}}} v_{1}(1),\right. \\
v_{1_{e_{1}}} v_{1}(1), v_{2_{e_{1}}} v_{2}(1), v_{2_{e_{2}}} v_{2}(1), v_{3_{e_{2}}} v_{3}(1), \\
\left.v_{3_{e_{3}}} v_{3}(1), \ldots, v_{n_{e_{n-1}}} v_{n}(1), v_{n_{e_{n}}} v_{n}(1)\right\}
\end{array}
\end{aligned}
$$

Jadi graf baru $C_{n}{ }^{*}=\left(V^{*}, E^{*}\right)$ dengan fungsi $f\left(v_{i}\right)=1$ untuk $i=1,2, \ldots, n$ adalah:

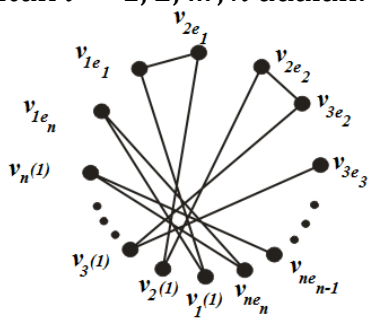

Gambar 25 Graf Baru $C_{n}{ }^{*}$ untuk $n$ Genap dari Fungsi $f\left(v_{i}\right)=1$ untuk $i=1,2, \ldots, n$

Selanjutnya dari Gambar 25 dilakukan faktorisasi dengan menunjukkan adanya pasangan yaitu dengan melihat pengembangan titik yang terjadi dari setiap titik di graf sikel $C_{n}$ berdasarkan masingmasing pemetaannya sebagaimana berikut:

Untuk $v_{1}$ dipetakan ke 1 , maka diperoleh $D\left(v_{1}\right)=\left\{v_{1 e_{n}}, v_{1 e}\right\}$ dan $S\left(v_{1}\right)=\left\{v_{1}(1)\right\}$. Jadi titik $v_{1}$ berkembang menjadi $\left\{v_{1 e_{n}}, v_{1 e_{1}}, v_{1}(1)\right\}$

Untuk $v_{2}$ dipetakan ke 1 , maka diperoleh $D\left(v_{2}\right)=\left\{v_{2_{e_{1}}}, v_{2_{e_{2}}}\right\}$ dan $S\left(v_{2}\right)=\left\{v_{2}(1)\right\}$. Jadi 
titik $v_{2}$ berkembang menjadi DAFTAR PUSTAKA

$\left\{v_{2_{1}}, v_{2_{2}}, v_{2}(1)\right\}$

Untuk $v_{n}$ dipetakan ke 1 , maka diperoleh $D\left(v_{n}\right)=\left\{v_{n_{e_{n-1}}}, v_{n_{e_{n}}}\right\}$ dan $S\left(v_{n}\right)=\left\{v_{n}(1)\right\}$. Jadi titik $v_{n}$ berkembang menjadi $\left\{v_{n_{e_{n-1}}}, v_{n_{e_{n}}}, v_{n}(1)\right\}$

Dari pengembangan titik ini dapat dilihat bahwa untuk setiap titik yang dipetakan ke 1 selalu berkembang menjadi 3 titik, karena sebanyak $n$ titik yang dipetakan ke 1 maka banyak pengembangannya adalah $3 n$ titik, dan karena $n=2 k+2$ maka $3 n=$ $3(2 k+2)$ bernilai genap. Kemudian dari simulasi Gambar 3.21 terlihat bahwa sisi-sisi yang terbentuk pada graf baru $C_{n}{ }^{*}$ berupa lintasan, sehingga dapat ditunjukkan himpunan pasangannya adalah $M=$ $\left\{v_{3_{e_{3}}} v_{3}(1), \quad v_{3_{e_{3}}} v_{2_{e_{2}}}, \quad v_{2_{e_{1}}} v_{2}(1), v_{1_{e_{1}}} v_{1}(1)\right.$, $\left.v_{e_{n}} v_{n_{e_{n}}}, v_{n_{e_{n-1}}} v_{n}(1)\right\}$, maka dapat dipastikan graf baru $C_{n+2}{ }^{*}$ dengan fungsi sebanyak $n$ titik dipetakakan ke 2 akan selalu memiliki 1faktor.

\section{PENUTUP}

\section{Kesimpulan}

Berdasarkan pembahasan, maka dapat diperoleh kesimpulan bahwa ciri-ciri fungsi yang mengakibatkan graf baru $C_{n}{ }^{\star}$ yang dihasilkan dari kemungkinan-kemungkinan fungsi $f: V\left(C_{n}\right) \rightarrow\{1,2\}$ dapat memiliki 1faktor adalah:

Untuk $n$ ganjil

a. Fungsi dengan sebanyak $n$ titik dipetakan ke 2

b. Fungsi dengan sebanyak hanya satu titik dipetakan ke 2

Untuk $n$ genap

a. Fungsi dengan sebanyak $n$ titik dipetakan ke 2

b. Fungsi dengan sebanyak $n$ titik dipetakan ke 1

\section{Saran}

Bagi penelitian selanjutnya disarankan untuk melanjutkan penelitian pada graf lain.
[1] Bollobas, B. (1978). EXTREMAL GRAPH THEORY. San Francisco: ACADEMIC PRESS.

[2] Bondy, J., \& Murty, U. (2008). Graph Theory. USA: Springer.

[3] Budayasa. (2007). Teory Graph dan Aplikasinya. Surabaya: Unesa University Press.

[4] Chartrand, G., \& Lesniak, L. (1986). Graph and Digraphs. Washington: Chapman \& Hall/CRC.

[5] Munir, R. (2012). Matematika Diskrit. Bandung: Informatika Bandung. 